\title{
TEACHERS' SELF-ASSESSMENT OF THE COMPETENCIES OF LEARNING TO LEARN AND REFLECTION IN THE CONTEXT OF SCHOOL AS A LEARNING ORGANIZATION
}

\author{
Remigijus Bubnys \\ Šiauliai University, Lithuania \\ Greta Pilkienè \\ Šiauliai University, Lithuania \\ Benas Gudinavičius \\ Šiauliai State College, Lithuania
}

\begin{abstract}
This article analyses teachers' self-assessment of the competencies of learning to learn and reflection in the context of school as a learning organization. The survey in the form of a written questionnaire was performed and 141 teachers of the city of Vilnius have participated in it. The research reveals the self-assessment results of the skills in the field of time evaluation, planning and management; information search, perception, systematization and adaptation; communication and cooperation in group; and reflection. Teachers highlight the sufficiency of the time distribution for tasks and deadlines skills; awareness and lower level skills of systematization of the information; skills of reception of comments from the members of the group, their consideration or the listening and understanding of the views of the members; skills of abstract conceptualization, which are related to drawing conclusions and anticipating ideas for the future.
\end{abstract}

Keywords: competence, teacher, learning to learn, reflection.

\section{Introduction}

At school as a learning organization, there is a constant improvement clause, fostered and supported by a learning process, a positive microclimate, and new ideas are generated and innovations are being implemented. A good school is a constantly learning organization whose community is reflective: pondering and discussing its activities and events of shared life, appreciates the ability to learn from experience and reasonably plan (Geros mokyklos koncepcija, 2013). For teachers, the implementation of the Education in the Europe 2020 strategy is becoming more significant, increasing demands and qualifications of the teacher in order to achieve the essential goals: making lifelong learning a reality; improving the quality and efficiency of education and training; strengthening 
Bubnys et al., 2020. Teachers' Self-Assessment of the Competencies of Learning to Learn and Reflection in the Context of School as a Learning Organization

social justice and active citizenship; promoting creativity, innovation and entrepreneurship (Education in the Europe 2020 Strategy, 2010). Educators inevitably face changes that lead to expanding their horizons, acquiring new knowledge and improving existing knowledge. Each task is seen as an opportunity to learn from successes and failures, and allows experimentation and analysis of its practices. Positive changes in school, as a learning organization, take place when the entire school community is enrolled in planning, reflection, and training in order to improve its operational practices. The learning school is dominated by a culture of reflective learning - all members of the organization respect, encourage, support and learn from each other. Reflection on professional activity identifies and modifies the personal assumptions that are based on practice. It allows finding alternative answers to questions and possible solutions to problems, thus better understanding the subtlety of professional activities. Openness to the world means that members of the school community are interested in a changing environment and responsive to change.

In recent years, the problem of reflection in the context of professional activity is becoming more pressing. A global and fast-changing social space raises new challenges to have critical thinking, decision-making and continuous learning skills. The perception of reflection begins with understanding about what you are doing and ends with a critical assessment of your ideology and beliefs influenced by thinking and feelings during activity. It is important to create conditions for learning to learn and to cultivate a reflection, including essential elements personality experiences, thinking, emotions, actions and values in the social and political context in which the learner lives. Professional reflection can be characterised as a process of reviewing know-how to describe, analyse, evaluate and thus learn from your experience (Boud, Keogh, \& Walker, 2005; Bradbury, 2010).

A teacher's reflective practice involves considering a careful "vision" and "action" to enhance the learning experience. By studying their practice and reflecting meaningful experiences, teachers are more easily expressing their thoughts (Fook \& Gardner, 2007), and this reflection enhances teaching and learning (Rushton \& Suter, 2012). Reflection promotes teachers' professional learning as an effective development of metacognitive skills (Hegarty, 2011) in order to achieve individual, community and organizational solutions for activities, learning, objectives, urgent or future changes in practice (Tikkamaki \& Hilden, 2014). On the other hand, reflective practices are perceived as thinking about teaching. It is like a form of travel, where it is encouraged to reflect on various forms of training. All this enables to think about what is being done (RoffeyBarentsen \& Malthouse, 2013). The nature of teachers' learning needs is unstable, requires a continuous renewal of the structure of professional development, focusing not on static knowledge creation, but on the construction of meaningless 
in a common environment. Such an update promotes the inner process of cognitive development leading to the improvement of teachers (Pitsoe \& Maila, 2013). This creates practical opportunities to draw attention to the results of professional development by encouraging teachers to create, disseminate and reflect their experiences. By thinking about their thoughts, feelings, behaviors, and assessments, they justify the reflective practices as means to achieve their goals (Finlay, 2008). In order to achieve the objectives, the reflective practice manifests itself as an innovative, continuous process that requires an understanding of the skills or knowledge creation slots, which is characterised by effectiveness (Wagner, 2006).

By learning and pondering their practice, teachers create self-knowledge and develop a reflective intelligence (Hilden \& Tikkamaki, 2013). This development of mind together leads to personal growth and development based on deep understanding (Raelin, 2002), which is manifested through bold self-listening, based on insights (Bolton, 2010). The reflecive practice of the teacher promotes dialogue with himself and appeals to experience emotions into personal development, perceived by his feelings (Bishop \& Blake, 2007; RoffeyBarentsen \& Malthouse, 2013), identity formation (Finlay, 2008; Hall, 2010). Personal questions about their practice help to perceive the role of teacher (Laker, 2001; Wagner, 2006), which leads to awareness and understanding, which determines the initiative, supports the change of practice leading to behavioural change (York-Barr, Sommers, Ghere, \& Montie 2001). Based on the insights and assumptions provided, the problematic question of study is formulated: What are the teachers' self-evaluations of the competency of learning to learn and reflection in the context of school as a learning organization.

Research object - trends in the teachers' self-assessment of the competency of learning to learn and reflection

The aim of the research is to analyse the trends in the teachers' selfassessment of the competency of learning to learn and reflection in the context of school as a learning organization.

\section{Material and Methods}

Sample. The research sample was formed using targeted and convenient selection methods. The research involved $141(100 \%)$ teachers working in Vilnius city general education schools, of which $97.9 \%$ women and $2.1 \%$ men. The average age is 48 years. The majority (74.1\%) teachers who have participated in the research have a degree of university education.

Research methods. Data collection method: written survey using closed type questionnaire. The questionnaire was prepared after the operationalisation of the phenomenon, distinguishing four main diagnostic areas: 
Bubnys et al., 2020. Teachers' Self-Assessment of the Competencies of Learning to Learn and Reflection in the Context of School as a Learning Organization

1) Self-assessment of time evaluation, planning and management competence;

2) Self-assessment of information search, perception, systematization and adaptation competence;

3) Self-assessment of communication and cooperation in group competence;

4) Self-assessment of reflection competence. The questionnaire was completed by the teachers by evaluating each statement submitted which reflects their personal skills. They had to choose one of the three response levels: „Sufficient”, „Average”, „Weak”. Data processing methods: descriptive statistics using SPSS for Windows 23.0 software.

\section{Research Results}

Tables 1-3 summarises the competences of learning to learn and in table 4 the results of the self-assessment of teachers' competence of reflection are shown. Table 1 presents the results of the self-assessment of teacchers' time evaluation, planning and management competence.

Table 1 Self-assessment of time evaluation, planning and management competence

\begin{tabular}{|c|l|c|c|c|}
\hline No. & \multicolumn{1}{|c|}{ Skills } & Sufficient & Average & Weak \\
\hline 1. & Allocate time for demanding tasks & 89.3 & 10.7 & - \\
\hline 2. & Comply with the deadlines for tasks & 84.1 & 15.9 & - \\
\hline 3. & $\begin{array}{l}\text { Ask for help and use all resources to accomplish } \\
\text { tasks in a timely manner }\end{array}$ & 79.3 & 20.0 & 0.7 \\
\hline 4. & $\begin{array}{l}\text { To analyse the reasons for not complying with } \\
\text { the deadlines and to determine whether they } \\
\text { were deliberate or unconscious }\end{array}$ & 74.1 & 25.2 & 0.7 \\
\hline 5. & $\begin{array}{l}\text { Assess the time needed for the task or activity to } \\
\text { be successfully completed }\end{array}$ & 73.4 & 26.6 & - \\
\hline 6. & $\begin{array}{l}\text { Terminate an activity and reschedule it when the } \\
\text { goal is not visible or the planned tasks are not } \\
\text { fulfilled }\end{array}$ & 69.3 & 26.4 & 4.3 \\
\hline 7. & $\begin{array}{l}\text { Predict the likelihood of surprises and plan the } \\
\text { time to complete the task even if surprises occur }\end{array}$ & 58.9 & 31.9 & 9.2 \\
\hline 8. & $\begin{array}{l}\text { Time schedule and lead a blog to remember, } \\
\text { organize and plan your activities }\end{array}$ & 58.6 & 22.9 & 18.6 \\
\hline 9. & $\begin{array}{l}\text { Develop strategies to overcome obstacles that } \\
\text { hinder compliance with deadlines }\end{array}$ & 57.2 & 42.8 & - \\
\hline 10. & $\begin{array}{l}\text { Depending on the deadlines set for the task, to } \\
\text { set the start and end times for each task }\end{array}$ & 55.0 & 39.3 & 5.7 \\
\hline
\end{tabular}


The results obtained suggest that the teachers in the context of time evaluation, planning and management competence have assessed their existing skills for time distribution for tasks and deadlines as sufficient. This could be coupled with an effective time-planning and management process. However, it is noted that more complex skills for the development of time-planning, time use monitoring and management strategies are not assessed as well. We would assume that it is precisely the possession of these abilities to ensure the effectiveness of the time management process.

The knowledge society determines a work scenario in which it is essential to manage time efficiently (Alvarez Sainz, Ferrero, \& Ugidos, 2019). According to the authors, the decisive factor is not the amout of time available but the management that is made of it. S. Zafarullah and V. Pertti (2017) mark that time management skills are associated with the allocation of time across the job tasks and higher measures of job performance. Time allocation is critical for managing instruction and improving performance.

Table 2 presents the results of self-assessment of teachers' competence of the information search, perception, systematization and adaptation.

Table 2 Self-assessment of information search, perception, systematization and adaptation competence

\begin{tabular}{|c|l|c|c|c|}
\hline No. & \multicolumn{1}{|c|}{ Skills } & Sufficient & Average & Weak \\
\hline 1. & Understand the basic idea of a conversation & 95.0 & 5.0 & - \\
\hline 2. & Organize information based on criteria & 89.9 & 10.1 & - \\
\hline 3. & $\begin{array}{l}\text { Follow and explain the consistency of } \\
\text { instructions in writing or visually }\end{array}$ & 88.5 & 11.5 & - \\
\hline 4. & Identify available resources for information & 87.9 & 12.1 & - \\
\hline 5. & $\begin{array}{l}\text { Understand the basic words and the main idea } \\
\text { of the text or the author's preferences }\end{array}$ & 87.2 & 12.8 & - \\
\hline 6. & $\begin{array}{l}\text { Categorize information items by category when } \\
\text { you need to select }\end{array}$ & 85.7 & 11.4 & 2.9 \\
\hline 7. & $\begin{array}{l}\text { Use simple memorization strategies to keep } \\
\text { your daily life in note }\end{array}$ & 85.0 & 15.0 & - \\
\hline 8. & $\begin{array}{l}\text { To systematize the information so that I can } \\
\text { easily find }\end{array}$ & 78.6 & 20.7 & 0.7 \\
\hline 9. & $\begin{array}{l}\text { Reproduce text structure and content using plan } \\
\text { and mind map }\end{array}$ & 78.6 & 20.7 & 0.7 \\
\hline 10. & Access to information resources & 77.3 & 15.6 & 7.1 \\
\hline
\end{tabular}

The awareness and lower level skills of systematization of the information is observed to be the highest, but the ability to search and adapt information is perceived as weaker. One of the reasons for this can be a very large flow of information around the teacher, in the context of which it is difficult to select the 
Bubnys et al., 2020. Teachers' Self-Assessment of the Competencies of Learning to Learn and Reflection in the Context of School as a Learning Organization

necessary and useful information, secondly, the adaptation of information in the future perspective is directly linked to the successful systematization.

The role of information in supporting processes has become increasingly important. In today's competitive world, information management has become a "prerequisite" for process management. The role of information management as the driver of process management and its impact on performance is very relevant (Projogo, Joy, Bhattacharya, Oke, \& Cheng, 2018).

Table 3 presents the results of the self-assessment of teaachers' communication and cooperation in group competence.

Table 3 Self-assessment of communication and cooperation in group competence

\begin{tabular}{|c|l|c|c|c|}
\hline No. & \multicolumn{1}{|c|}{ Skills } & Sufficient & Average & Weak \\
\hline 1. & $\begin{array}{l}\text { Accept comments from group members, } \\
\text { consider their usefulness and correct errors }\end{array}$ & 94.2 & 5.1 & 0.7 \\
\hline 2. & $\begin{array}{l}\text { Listening and understanding of other people's } \\
\text { attitudes - when it coincides with me and when } \\
\text { it differs }\end{array}$ & 91.3 & 8.7 & - \\
\hline 3. & $\begin{array}{l}\text { Adopt the group's rules of work and comply } \\
\text { with these rules }\end{array}$ & 91.3 & 8.7 & - \\
\hline 4. & $\begin{array}{l}\text { Positively negotiate with the group members in } \\
\text { search of solutions for problems }\end{array}$ & 90.6 & 9.4 & - \\
\hline 5. & $\begin{array}{l}\text { Recognise and assess any contribution of a } \\
\text { group member to the joint work }\end{array}$ & 89.1 & 10.9 & - \\
\hline 6. & Actively participate in the work of the group & 82.7 & 17.3 & - \\
\hline 7. & Receive assistance from group members & 82.6 & 17.4 & - \\
\hline 8. & $\begin{array}{l}\text { Encourage group members to engage in } \\
\text { activities }\end{array}$ & 78.3 & 21.7 & 3.6 \\
\hline 9. & $\begin{array}{l}\text { Accept team decisions even when I disagree } \\
\text { with them }\end{array}$ & 68.8 & 27.5 & 2.2 \\
\hline 10. & $\begin{array}{l}\text { To express own view to the group even when it } \\
\text { differs from the opinion of others }\end{array}$ & 66.7 & 31.2 & - \\
\hline
\end{tabular}

The results show that the teachers better assessed the skills of their communication in a group related to the reception of comments from the members of the group, their consideration or the listening and understanding of the views of the members. The skills of the team's decision-making or encouraging others to participate in the activities were clearly assessed as weaker. It is likely that it is easier for teaachers to share information, feelings, thinking on the contents of a conversation, what until then, before communicating, was not common, but it is more difficult to work together, focusing on intellectual forces, helping to each other, uniting or acting together. 
Previous studies have indicated that when teachers are effective classroom managers, their students achieve at a higher level (Omoteso \& Samudara, 2011; Stronge, Ward, \& Grant, 2011; Stronge, Ward, Tucker, \& Hindman, 2008) and display more interest in the class subject matter.

Table 4 presents the results of the self-assessment of teacchers' reflection competence.

Table 4 Self-assessment of reflection competence

\begin{tabular}{|c|l|c|c|c|}
\hline No. & \multicolumn{1}{|c|}{ Skills } & Sufficient & Average & Weak \\
\hline 1. & $\begin{array}{l}\text { Identify what lessons can be learnt from the } \\
\text { experience now or in the future }\end{array}$ & 94.3 & 5.7 & - \\
\hline 2. & $\begin{array}{l}\text { Assess whether the objectives of learning } \\
\text { activities have been achieved }\end{array}$ & 93.6 & 6.4 & - \\
\hline 3. & $\begin{array}{l}\text { Assess what was good in the previous } \\
\text { experience and what is changeable }\end{array}$ & 91.4 & 7.9 & 0.7 \\
\hline 4. & $\begin{array}{l}\text { To identify experience from the previous } \\
\text { activities }\end{array}$ & 87.9 & 11.4 & 0.7 \\
\hline 5. & $\begin{array}{l}\text { Predict in what activities, how and in what way } \\
\text { I will apply the previous experience }\end{array}$ & 84.9 & 15.1 & - \\
\hline 6. & $\begin{array}{l}\text { Determine what previous learning activities } \\
\text { were effective }\end{array}$ & 84.8 & 15.2 & - \\
\hline 7. & $\begin{array}{l}\text { Identify what was important in previous } \\
\text { learning activities }\end{array}$ & 82.1 & 17.1 & 0.7 \\
\hline 8. & $\begin{array}{l}\text { Find a theoretical justification for previous } \\
\text { experience }\end{array}$ & 81.4 & 17.1 & 1.4 \\
\hline 9. & $\begin{array}{l}\text { Describe the circumstances in which the } \\
\text { previous learning experience was acquired }\end{array}$ & 74.8 & 22.3 & 2.9 \\
\hline 10. & $\begin{array}{l}\text { Reveal feelings that I have experienced in } \\
\text { learning activities }\end{array}$ & 67.4 & 28.3 & 4.3 \\
\hline
\end{tabular}

It can be noted that different skills of reflection competence were assessed unevenly by the teachers. The subjects had very well assessed their skills of abstract conceptualization, which are related to drawing conclusions and anticipating ideas for the future. The skills of disclosure of a specific experience and reflective observation were assessed as weaker. These skills are related to the perception and reception of experience. The skills of active experimentation (anticipating and conducting future actions) is to be seen in the same way as very good.

Teachers' ability to critically reflect classroom situations in relation to their own actions constitutes an important prerequisite to improve teaching performance and professional behavior (Rominger, Reitinger, Seyfried, Schneckenleitner, \& Fink, 2017). Many scientific sources (Soleil, 2000; Osterman \& Kottkamp, 2004; Pollard, 2006; Correia \& Bleicher, 2008) are 
Bubnys et al., 2020. Teachers' Self-Assessment of the Competencies of Learning to Learn and Reflection in the Context of School as a Learning Organization

emphasising that it is important to become a researcher of our activities and experience, anticipating prospects for more efficient solutions to future problems, discovering new ways, verifying assumptions and applying ideas in specific practical situations. The results of the study show that teachers highly appreciate these abilities, but the analysis of their feelings and the reflection of the circumstances of previous experience, as evidenced by other studies (Felten, Gilchrist, \& Darby, 2006; Shapiro, 2009; Guvenc \& Celik, 2012; Zembylas, 2014) are considered as insufficient. Emotions and feelings are a significant source of learning to learn and the motivator of reflection, but often they become an obstacle to successfully learning from the experience. Depending on the circumstances and intentions, it is important to analyze our emotional experiences, find ways to avoid them or - maintain and strengthen them if the latter are positive.

\section{Conclussions}

In the context of learning to learn competence teachers assessed their skills of understanding the basic idea of a conversation, accepting comments from group members, considering their usefulness and correcting errors, listening and understanding of other people's attitudes as the most sufficient. The research results showed that teachers' time evaluation, planning and management competence is assessed weaker than information search, perception, systematization and adaptation or communication and cooperation in group competencies.

Research results on assessing teachers' reflection competence demonstrate that abstract conceptualization skills such as drawing conclusions and anticipating ideas for the future are the most sufficient. The skills of active experimentation (anticipating and conducting future actions) were assessed as sufficient too. Teachers emphasized that the skills of revealing feelings experiencen in learning activities are more wearker than the other ones.

\section{References}

Alvarez Sainz, M., Ferrero, A., \& Ugidos, A. (2019). Time management: skills to learn and put into practice. Education and Training, 60, 1. Retrieved from https://www.researchgate. net/publication/330977996_Time_management_skills_to_learn_and_put_into_practice

Bishop, G., \& Blake, J. (2007). Reflective Practice: A Guide to Reflective Practice with Workbook: For Post Graduate and Post Experience Learners. UK: University of Huddersfield.

Bolton, G. (2010). Reflective practice: writing and professional development. London: Sage

Boud, D., Keogh, R., \& Walker, D. (2005). Reflection: Turning Experience into Learning. London and NewYork: RoutledgeFalmer.

Bradbury, H. (2010). Beyond Reflective Practice: New Approaches to Professional Lifelong Learning. London: Routledge. 
Correia, M.G., \& Bleicher, R. (2008). Making Connections to Teach Reflection. Michigan Journal of Community Service Learning, 14(2), 41-49. Retrieved from http://hdl.handle.net/2027/spo.3239521.0014.204

Felten, P., Gilchrist, L.Z., \& Darby, A. (2006). Emotion and Learning: Feeling our Way toward a New Theory of Reflection in Service-Learning. Michigan Journal of Community Service Learning, 12(2), 38-46.

Finlay, L. (2008). Reflecting on Reflective Practice. PBPL paper, 52, 1-27. Retrieved from https://www.semanticscholar.org/paper/Reflecting-on-\%E2\%80\%98-Reflectivepractice-\%E2\%80\%99-Finlay/2988c18f4f2735108553f46f628fe285a2287226

Fook, J., \& Gardner, F. (2007). Practising Critical Reflection: A Resource Handbook. Maidenhead: McGraw-Hill Education: Open University Press.

Geros mokyklos koncepcija. (2015). Patvirtinta Lietuvos Respublikos švietimo ir mokslo ministro $2015 \mathrm{~m}$. gruodžio $21 \mathrm{~d}$. issakymu Nr. V-1308. Retrieved from https://www.smm.lt/uploads/documents/Pedagogams/Geros\%20mokyklos\%20koncepci ja.pdf

Guvenc, Z., \& Celik, K. (2012). The Relationship between the Reflective Thinking Skills and Emotional Intelligences of Class Teachers. International Journal of Humanities and Social Science, 2(16), 223-234. Retrieved from https://www.academia.edu/ 3430678/The_Relationship_between_the_Reflective_Thinking_Skills_and_Emotional_ Intelligences_of_Class_Teachers

Hall, J. (2010). Making Art, Teaching Art, Learning Art: Exploring the Concept of the Artist Teacher. International Journal Of Art. Design education, 29(2), 103-110. DOI: http://dx.doi.org/10.1111/j.1476-8070.2010.01636.x

Hegarty, B. (2011). Is Reflective Writing an Enigma? Can Preparing Evidence for an Electronic Portfolio Develop Skills for Reflective Practice? In G. Williams, P. Statham, N. Brown, B. Cleland (Eds.), Changing Demands, Changing Directions Proceedings Ascilite (pp. 580-593).

Hilden, S., \& Tikkamaki, K. (2013). Reflective Practice as a Fuel for Organizational Learning. Administrative Sciences, 3(3), 76-95. DOI:10.3390/admsci3030076

Laker, A. (2001). Developing Personal, Social, Moral Education through Physical EducationA Practical Guide for Teachers. USA and Canada: Routledge/Falmer.

Omoteso, B., \& Samudara, A. (2011). The Relationship between Teachers' Effectiveness and Management of Classroom Misbehaviors in Secondary Schools. Psychology, 2, 902-908. DOI: $10.4236 /$ psych.2011.29136

Osterman, K.F., \& Kottkamp, R.B. (2004). Reflective Practice for Educators. Professional Development to Improve Student Learning. California: Corwin Press.

Pitsoe, V., \& Maila, M. (2013). Re-thinking Teacher Professional Development through Schon's Reflective Practice and Situated Learning Lenses. Mediterranean Journal of Social Sciences, 4(3), 211-218. DOI: 10.5901/mjss.2013.v4n3p211

Pollard, A. (2006). Refleksyvusis mokymas. Veiksminga ir duomenimis paremta profesine praktika. Vilnius: Garnelis.

Prajogo, D., Toy, J., Bhattacharya, A., Oke, A., \& Cheng, T.C.E. (2018). The relationships between information management, process management and operational performance: Internal and external contexts. International Journal of Production Economics, 199, 95-103.

Raelin, J.A. (2002). "I Don’t Have Time to Think!” Versus the Art of Reflective Practice. Reflections, 4(1), 66-79. DOI: 10.1162/152417302320467571 
Bubnys et al., 2020. Teachers' Self-Assessment of the Competencies of Learning to Learn and Reflection in the Context of School as a Learning Organization

Roffey-Barentsen, J., \& Malthouse, R. (2013). Reflective Practice in Education and Training. London: Sage.

Rominger, C., Reitinger, J., Seyfried, C., Schneckenleitner, E., \& Fink, A. (2018). The Reflecting Brain: Reflection Competence in an Educational Setting Is Associated With Increased Electroencephalogram Activity in the Alpha Band. Mind, Brain, and Educatio, 11(2), 54-63.

Rushton, I., \& Suter, M. (2012). Reflective Practice for Teaching in Lifelong Learning. McGraw-Hill: Open University press.

Shapiro, S. (2009). Revisiting the Teachers' Lounge: Reflections on Emotional Experience and Teacher Identity. Teaching and Teacher Education, 4, 1-6. DOI: 10.1016/j.tate.2009.09.009

Soleil, N. (2000). Toward a Pedagogy of Reflective Learning: Lived Experience in Research and Practice. New Directions for Teaching and Learning, 31(1), 73-83. DOI: 10.1080/10790195.2000.10850103

Stronge, J.H., Ward, T.J., \& Grant, L.W. (2011). What Makes Good Teachers Good? A CrossCase Analysis of the Connection between Teacher Effectiveness and Student Achievement. Journal of Teacher Education, 62(4), 339-355. DOI: $10.1177 / 0022487111404241$

Stronge, J.H., Ward, T.J., Tucker, P.D., \& Hindman, J.L. (2008). What is the relationship between teacher quality and student achievement? An exploratory study. Journal of Personnel Evaluation in Education, 20(3-4), 165-184. DOI: 10.1007/s11092-0089053-z

Tikkamaki, K., \& Hilden, S. (2014). Making Work and Learning More Visible by Reflective Practice. Research in Post-Compulsory Education, 19(3), 287-301. DOI: 10.1080/13596748.2014.920577

Wagner, K. (2006). Benefits of Reflective Practice. Leadership, 36(2), 30-32. Retrieved from https://eric.ed.gov/?id=EJ771713

York-Barr, J., Sommers, W.A., Ghere, G.S., \& Montie, J. (2001). Reflective Practice and Continuous Learning. In Reflective Practice to Improve Schools: An Action Guide for Educators. California: Corwin Press.

Zembylas, M. (2014). The Place of Emotion in Teacher Reflection: Elias, Foucault and 'Critical Emotional Reflexivity’. Power and Education, 6(2), 210-222. DOI: 10.2304/power.2014.6.2.210

Zafarullah, S., \& Pertti, V. (2017). Effect of Time Management on the Job Satisfaction and Motivation of Teacher Educators: A Narrative Analysis. International Journal of Higher Education, 2, 213-224. 